\title{
On Violence and Repression: A Relational Approach (The Government and Opposition/Leonard Schapiro Memorial Lecture, 2013)
}

\begin{abstract}
Oppositional violence and repression are closely related. In fact, repression often produces an escalation of violence rather than controlling it. Bridging social movement studies and research on violence, the article uses a small-N, mostdifferent research design to analyse the working of a specific mechanism at the onset of different types of political violence: escalating policing. In particular, it indicates specific causal mechanisms, related to interactions between social movements and the state, which create the conditions for some splinter groups to move underground. In order to compare left-wing, right-wing, ethno-national and religious violence, the article presents empirical references to the author's own empirical research on Italy and the Basque Country as well as a secondary analysis of the conflicts that preceded the rise of al-Qaeda.
\end{abstract}

ON 11 SEPTEMBER 2001, AROUND 3,000 PEOPLE DIED IN A SERIES OF coordinated suicide attacks by al-Qaeda upon the USA. On 22 July 2011, Anders Breivik, a militant from the extreme right, killed eight people in the bombing of government buildings in Oslo and shot another 69, mostly teenagers, who were participating in a camp run by the Norwegian Labour Party Workers' Youth League (AUF) on the island of Utøya. These episodes, and the forms of political violence they illustrate, have mainly been interpreted through a socalled 'breakdown' approach that sees perpetrators as affected by mental pathologies and the systemic level as characterized by strains and dysfunctions (della Porta 2013: ch. 1).

Islamic fundamentalism has often been considered within the discourse of a clash of civilizations, fuelled by globalization. In particular, after 9/11, so-called 'terrorism studies' emphasized some new characteristics of religious fundamentalism. Political violence by Islamic fundamentalists has, in fact, been marked as distinctive in several ways. New, religious forms of violence are said to be more 
indiscriminate than past ones, as especially evil and cruel, using the most lethal means. As goals are seen as absolute and not negotiable, new 'religious' terrorists have been attributed motivations such as fanaticism, rage, sadism and paranoia (Laqueur 2003).

Political violence on the radical right - of which Breivik's attacks were a most dramatic manifestation - is represented as a mirror image of the religious fundamentalist type of violence. The concept of 'lone-wolf' terrorism has been applied in the analysis of what has indeed been defined as anti-Islamist violence, stressing the perpetrators' mental disorders and lack of social ties (Berntzen and Sandberg forthcoming).

Different approaches have sprung up in the analysis of ethnonationalist or left-wing ideological forms of violence. The former have been addressed particularly by scholars of nationalism, focusing on the dynamics of a long history of (tense) relations between centre and periphery, with the former exploiting the latter. Left-wing political violence has also been located in long-lasting conflicts, but in this case addressed - at least more often than the other types - in a social movement approach that looks at the political and social transformations that affect class cleavages. Although the use of violent means has often been stigmatized and considered as ultimately ineffective, research on both left-wing and nationalist forms has tended to locate violent groups within broader social and political (even if radicalized) conflicts.

Are these divergent interpretations of political violence carried out by people from different ideological leanings justified by actual empirical differences? Or do they reflect the different preferences and biases of different disciplinary subfields? Empirical answers to these questions are not yet offered by the political and social sciences, as comparative politics has in fact usually - consciously or unconsciously - privileged the comparison of 'like with like', often within an area studies perspective. Southern Europe, Central Europe, the Middle East and Eastern Europe have indeed been much-studied areas in comparative terms, and with rich results. As long as comparative methods have been understood as (weaker) versions of experimental or statistical ones, within-area comparisons have been privileged indeed, as they allow researchers to address the traditional problem of 'many variables, few cases' by making parameters of as many potentially intervening variables as possible, and by focusing on a few differences (della Porta 2008a). 
Additionally, on this topic as on others, the political and social sciences have focused on the west and the north of the globe, where core disciplines such as comparative politics and political sociology flourished, while specific forms of political violence developing in other areas of the world were left to the attention of area studies specialists. With all their value in attempting to go beyond ethnocentric visions of politics and society, area studies have been built around homogeneous geographical areas, each with their own focuses and biases. The very efforts involved in learning the histories and languages of these areas have pushed scholars towards high levels of specialization (for example, Burawoy 2005; della Porta 2014; Dutton 2005). Apart from a few valuable exceptions, different (area) specialists have addressed new waves of political violence in different geopolitical areas, stressing different aspects. A main theoretical assumption - either explicitly stated or implicitly accepted - is that, in a binary conceptualization of democracies versus non-democracies, comparisons should be bound within each class of phenomena.

While not denying the rich results from comparing 'like with like', the price paid for the dominance of a most-similar research design has been the lack of empirically founded answers to the question of the effective differences and similarities in phenomena which, different motivations notwithstanding, share some relevant characteristics, as they all refer to extreme forms of violence performed for political aims by individuals or small groups acting clandestinely. As Tilly (2004: 8) reminded us with specific reference to political violence, in the social sciences the value of a concept is linked to its capacity to 'point to detectable phenomena that exhibit some degree of causal coherence'. My research on left-wing political violence has considered the very choice of going underground by a relatively small group of activists to be heuristically relevant, as it triggers a spiral of radicalization, transforming political organizations into military sects. The extent to which clandestine political violence is a concept that could travel from the left-wing or ethnonationalist cases of the past to the most recent cases of religious and right-wing violence is a question that requires an empirically grounded answer.

Whether clandestine political violence of right-wing, left-wing, ethno-nationalist and religious inspirations does exhibit 'some degree of causal coherence' is indeed what I wanted to measure 
with research comparing these different types of violence (della Porta 2013). In order to do this, I suggest global comparison as a research design that might be fit to combine in-depth knowledge of case studies with the search for robust results more typical of large-N studies. Comparing a small number of cases cross-type would allow the researcher to assess the generalizability of explanations emerging on specific forms of political violence.

While global comparisons might help in addressing specific research questions, they should be handled with care, clarifying what they can do and what they cannot. First and foremost, the search for common causes as structural preconditions risks being frustrated when the range of the comparison increases. However, causal preconditions might not be the most pertinent questions to address phenomena that develop over time, interacting with different structural conditions and changing structures. Using global comparisons, I am, in fact, not interested in discovering general laws and invariant causes that could explain all the cases at hand. Rather, I want to identify some dynamics that are present in the evolution of these different cases of radicalization. In this sense, this research design allows us to move beyond the analyses that trace dissimilarities between similar types, and permits us to look instead for similarities in the way in which these different types developed (see also McAdam et al. 2001). Using the language introduced by Mahoney and Goertz (2006), the aim is not to provide a complete causal explanation of clandestine violence (by identifying the causes of an effect), but to investigate the effects of some specific mechanisms which I identify as being at work in various types of clandestine political violence. For this purpose, I use the concept of causal mechanisms.

In recent years, the language of mechanisms has become fashionable in the social sciences, signalling dissatisfaction with correlational analysis (Mahoney 2003). The concept of causal mechanism has been used to refer either to (historical) paths, with a search for events that are observable and context dependent, or to micro-level explanations, with a search for variables at the individual level in the quest for universal, law-like causal explanations. In macro-level analyses, causal mechanisms have been linked to systematic process that trace (Hall 2003) a causal reconstruction that seeks to explain a social phenomenon by identifying the process through which it is generated (Mayntz 2003). In micro-level 
explanations, instead, the theoretical focus is on individual agency. In particular, 'analytical sociology explains by detailing mechanisms through which social facts are brought about, and these mechanisms invariably refer to individuals' actions and the relations that link actors to one another' (Hedstrom and Bearman 2009: 4). In my understanding, mechanisms are categories of action that filter structural conditions and produce effects (see della Porta 2013). Following Tilly (2001), I conceptualize mechanisms as relatively abstract patterns of action that can travel from one episode to the next, explaining how a cause creates a consequence in a given context. I would not restrict capacity of action to individuals, however, instead including collective actors. Adapting Renate Mayntz's definition (2003), mechanisms are considered in the research as a concatenation of generative events linking macro causes (such as contextual transformation) to aggregated effects (for example, cycles of protest) through individual and/or organizational agents.

In what follows, I will illustrate the usefulness of a small-N, mostdifferent research design in analysing the working of a specific mechanism at the onset of different types of political violence: escalating policing. In particular, I will stress that, in all types, specific causal mechanisms, related to interactions between social movements and the state, created the conditions for some splinter groups to move underground. In order to compare left-wing, rightwing, ethno-national and religious violence, I will refer to my own empirical research on Italy and the Basque Country as well as a secondary analysis of the conflicts that preceded the rise of al-Qaeda (della Porta 2013). I will introduce the theoretical approach that I developed from within social movement studies, and then present the relational, cognitive and affective mechanisms that, in all the mentioned cases, converged at the onset of the formation of clandestine political organizations of various ideological leanings.

\section{DEVELOPING A DYNAMIC APPROACH TO CLANDESTINE POLITICAL VIOLENCE}

Previous research, especially on left-wing and ethno-nationalist clandestine organizations, has indicated that political violence often spreads during waves of protest. It frequently develops inside social movements and is indeed (although not often) a (most visible) byproduct of their actions. Most clandestine organizations have their 
roots in splits within social movement organizations, and most of the militants of underground organizations have previous experience in such organizations (della Porta 1995). Social movement studies provide, in fact, a useful conceptual instrument for building some relevant innovations into the research on political violence.

In social movement studies, explanations for protest strategies have been found primarily in the political opportunities available for social movements. The degree of institutional openness to challengers is influenced by some stable institutional features, such as functional differentiation and territorial decentralization, as well by as more contingent conditions such as the availability of allies or the instability of coalitions in power. The closer the political opportunities, the fewer and smaller - but also the more violent protests are expected to be. In research on political violence, low levels of freedom and democracy have also been linked to domestic terrorism in Western Europe (Engene 2004), and less proportional electoral systems to ethnic violence (Crenshaw 2011). The weakness of democracy, civil liberties, human rights, rule of law and so on are often considered to be root causes for violence of various types. When normal channels of access to the political system are blocked, extreme forms of political violence are perceived as necessary, as there is 'no other way out' (Goodwin 2004).

My previous work has indicated that activists react especially to a process proximate to their encounters with the state, particularly during the policing of protests - that is, the police handling of protest events: what protestors usually refer to as 'repression' and the state characterizes as 'law and order'. Protest policing has a direct impact on social movements, being a sort of barometer for the available political opportunities but also, given some mutable degree of discretion, directly affecting protest repertoires. In addition, it tends to vary for different actors and to develop in relation to the actors' behaviour. The analysis of protest policing allows for an understanding of those interactive processes that fuel violent escalation. Protestors and police, social movements and the state influence each other in the strategic choices they make, in a process involving innovation and adaptation on both sides (see also McAdam 1983). In fact, tough protest policing has characterized many cases in which political violence has developed (della Porta and Reiter 1998). Police control tends to affect the repertoires of protest through a reciprocal adaptation (or, sometimes, escalation)

(C) The Author 2014. Published by Government and Opposition Limited and Cambridge University Press 
of police and demonstrators' tactics (della Porta 1995). Protest and its policing 'is a dance between those who challenge authority, speak true to power, and hope for a more just world and those who wish to extend their privilege and power' (Fernandez 2008: 171). Crossnationally and transnationally, social movements and police strategies interact with each other in a process of double diffusion (della Porta and Tarrow 2012).

However, the debate is still ongoing on which levels and forms of repression produce escalations, as high levels of repression have proved effective in eliminating opposition in some cases, but counterproductive in others. Our four cases clearly differ on these dimensions, including authoritarian and democratic states, weak and strong ones. In addition, violence by ETA, the Basque nationalist and separatist group, increased as Spain was democratizing, and Islamist and antiIslamist violence hit some quite inclusive countries.

In fact, a structural vision of political opportunities (or lack thereof) as an explanation for the radicalization of clandestine groups has some shortcomings, especially in the analysis of clandestine political violence. First, small underground groups do react in a way that is at least somewhat deviant from broader contextual opportunities. Assessing the extent to which clandestine organizations act instrumentally is an open question to be addressed empirically. Moreover, much political violence develops in authoritarian regimes, or at least in imperfect democracies (or hybrid regimes). The analysis of political opportunities in research on political violence must be accompanied by some reflection on the relational, constructivist and emergent aspects of its development.

\section{Relational Violence}

Tilly (2004: 5) has suggested categorizing the scholars working on political violence as: ideas people, who look at ideologies; behaviour people, who stress human genetic heritage; and relational people, who 'make transactions among persons and groups much more central than do ideas or behavior people'. So, he continues, relational people focus their attention 'on interpersonal processes that promote, inhibit, or channel collective violence and connect it with nonviolent politics' (Tilly 2004: 20; see also McAdam et al. 2001: 22-4). Following a relational perspective, I suggest that repertoires emerge, and are transformed, in the course of physical and symbolic 
interactions between social movements and their opponents, and also through interactions with their potential allies. Changes take place in encounters between social movements and authorities in a series of reciprocal adjustments. Political violence is rarely adopted overnight or consciously. Rather, it follows a (more or less gradual) process, defined as 'actions of some kind associated with other actions and reactions, often expressed in some sort of reciprocal relationship' (Taylor and Horgan 2012: 130). Repeated clashes with police and political adversaries gradually and almost imperceptibly heighten radicalism, leading to a justification for ever more violent forms of action. In parallel, clandestine groups interact with a supportive environment where they find logistical help as well as symbolic rewards (Malthaner 2010). Indeed, violence has a relational component - deriving from interchanges between people - as interpersonal processes 'promote, inhibit or channel collective violence and connect it with nonviolent politics' (Tilly 2003: 20).

\section{Constructed Violence}

It has been observed that, in order to be acted upon, opportunities and constraints must be perceived by social movement activists. In this sense, what is important is not political institutions or distribution of power per se, but the framing of them - or, as McAdam et al. (2001) put it, the attribution of opportunities and threats. In this analysis, a main caveat is the need to consider the various actors' perceptions of similar contextual characteristics that is, how they are socially constructed. Looking at activists' construction of the external reality is all the more relevant as clandestine groups are usually tiny minorities reacting with extreme forms of violence to situations that are assessed differently by most of their fellow social movement activists. Cultural processes are particularly important for research on radical organizations, since political violence is mainly symbolic. Political violence develops in contexts in which some cultural resources are available; it produces heated debates on violence itself and, more than material damage, it aims at producing emotional effects. Beyond the instrumental dimension linked to increased visibility, an important consequence of direct action on the closer circles of protestors is the strengthening of motivations through the development of feelings of solidarity and belonging. Although the importance of emotions has long been 
viewed with suspicion (not only in social movement studies but in political sociology and political science generally), attention to their role has recently (re)emerged. Researchers have stressed the emotional intensity of participation in protest events as passionate politics (Aminzade and McAdam 2001; Goodwin et al. 2001), together with the role of subversive 'counter-emotions' in cementing collective identities (Eyerman 2005). The role of dramaturgy, narrative and rituals in intensifying commitment has been investigated for protest events in general (as an effect of an 'emotional liberation', see Flam 2005) as well as for specific critical emotional events. All of these elements are particularly relevant for understanding the emotionally intense experiences and specific cognitive processes in clandestine opposition organizations.

\section{Emergent Violence}

The concept of political opportunities is static. It tends to imply a direction of causality from contextual structures to actors' choices. In contrast, radicalization is a process that develops relationally. Opportunities and constraints for specific groups are created in the course of frequent interactions with the state. A good portion of the explanation of radicalization is in fact not in the political preconditions, but in the process. Violence has a processual, emergent character not accounted for by a causal model. Choices of violence develop in action. As Kalyvas (2006: 3) observed, 'almost every macrohistorical account of civil war points to the importance of preexisting popular allegiances for the war's outcome, yet almost every microhistorical account points to a host of endogenous mechanisms, whereby allegiances and identities tend to result from the war or are radically transformed by it.' Beyond the original cleavages, identities and interests, new ones are created, weakened or strengthened during the struggle. Motivations also change in action, as 'often civil wars politicize innocuous or non-violent prewar cleavages' (Kalyvas 2006: 79). Violence therefore acquires a logic of its own, producing the very same polarization that then fuels it. In Kalyvas' words (2006: 389), 'the advent of war transforms individual preferences, choices, behaviour, and identities - and the main way in which civil war exercises its transformative function is through violence . . Collective and individual preferences, strategies, values and identities are continuously shaped and 
reshaped in the course of the war.' Similarly, in guerrilla movements, as Elisabeth Wood (2003: 19) has observed, 'political culture - the values, norms, practices, beliefs, and collective identity of the insurgents - was not fixed but evolved in response to the experiences of the conflict itself, namely, previous rebellious actions, repression and the ongoing interpretation of events by the participants themselves.' I expect the same to happen for clandestine political violence, which in fact creates and re-creates the conditions of its own development.

\section{PROTEST AND REPRESSION: RELATIONAL, AFFECTIVE AND} COGNITIVE MECHANISMS

Research on political violence suggests a link between political opportunities and repertoires of action: repression is expected to produce escalation. Large-N studies have aimed to identify correlations between indicators of repression and indicators of political violence. However, the cases I have analysed present relevant differences in the contextual characteristics, including democracies and authoritarian regimes, the opening and closing of political opportunities. Still, notwithstanding the differences in the analysed contexts, militants' recollections point to some similar processes of escalation, distinguishing relational, affective and cognitive mechanisms.

\section{Relational Mechanisms}

Research on political violence on the left has indicated that the tougher the police strategies, the less they seemed able to stop the radicalization of protestors. First, repression tends to discourage the moderates, pushing them to return to private life and leave the protest arena to the more radical wings (see, for example, Tarrow 1989). Second, repression radicalizes even the moderates, through a process of solidarism. In particular, indiscriminate repression seemed to be the most counterproductive, as it enlarged the circles of victims and therefore the feelings of injustice.

In Italy, repression of the left, including the labour movement, was very strong in the 1940 s and 1950 s, when about 100 protestors lost their lives during police interventions (della Porta and Reiter 2004). After a period of de-escalation during the centre-left governments, tough forms of policing were used against a widespread cycle of 
protest that brought together students and workers (della Porta 1995). Even when mobilization declined in numbers and size, militancy remained high, re-emerging occasionally in violent forms. In these long-lasting processes, there was a reciprocal adaptation of tactics between police and protestors. Proceeding through reciprocal diffusion (della Porta and Tarrow 2012), escalation was relational. From the point of view of practices of violence, there was a reciprocal influence as well, with brutal behaviour on one side producing and reproducing brutal actions on the other. Stones, sticks and Molotov cocktails were used to protect the protestors from police baton charges; barricades were constructed to stop police; even firearms were used to respond to police shooting at demonstrators. Escalation thus developed in action. During the policing of protest, transformative events take place. In Italy, after the neo-fascist massacre at Piazza Fontana (1969) and with the proof that the Italian intelligence service had helped protect the assassins, the state became the 'state of the massacre', which made it 'right, there in Italy, to use mass violence against those responsible for the massacre perpetrated by the state' (Life history no. 12: 10; emphasis added $\left.^{1}\right)$.

Escalation continued to be a relational process. In the second half of the 1970s, as forms of protest became more militant, repression also became all the tougher. Throughout the decade, as right-wing and left-wing radicals engaged daily in brutal - sometimes deadly - fights, police strategies were unable to avoid escalation, using mass charges that hit peaceful protestors as well as agents provocateurs. On a few occasions in 1977 the army was mobilized to curtail prohibited marches by the extreme left, and firearms were used by both sides. On the extreme right, waves of repression were also cited as motivating Third Position (Terza Posizione) activists to join the Armed Revolutionary Group (Nuclei Armati Rivoluzionari NAR) (Cento Bull 2007: 143).

Similarly, parallel escalation by social movements and police forces characterized the onset of Islamist violence. In Egypt, the indiscriminate nature of much repression of violent Islamists brought about solidarity with them. Violence erupted when, at the end of the 1980s, the regime closed down other channels of institutional access and peaceful opposition that had slowly opened up at the end of the 1970s. It was in the first half of the 1980s that violence escalated, from 120 deaths between 1970 and 1989 to 1,442 between 1992 and 1997 (Cento Bull 2007: 71). Here, indeed, 'the 
cycle of violence began largely in response to a broad crackdown on the Islamic movement that ensnared moderates, radicals, and a number of tangential bystanders. The crackdown included arrests, hostage taking, torture, executions and other forms of state violence' (Hafez and Wiktorowicz 2004: 62). Torture as well as shoot-to-kill policies became widespread, along with the storming of mosques, mass arrests and executions. Repression was not only brutal, but also indiscriminate, hitting the militants of the violent organizations as well as their families and even 'anyone wearing a beard with a trimmed moustache' (Hafez and Wiktorowicz 2004: 78). Especially indiscriminate forms of repression 'antagonized hitherto inactive supporters and sympathizers and intensified the moral outrage of the activists' (Hafez and Wiktorowicz 2004: 70). From the mid-1990s the authorities intervened, 'moving ruthlessly against the militant groups and arresting tens of thousands of alleged members and supporters' (Hafez and Wiktorowicz 2004: 80).

Particularly relevant for the global network of Islamic fundamentalism were the former militants of the (US-supported) mujahideen resistance in Afghanistan and the numerous armed conflicts in the Middle East, Chechnya or former Yugoslavia, who contributed to the spread of a military vision. The Gulf War in 1990-91 was a turning point as it 'brought U.S. troops to the Arabian peninsula. The movement that became the global Salafi jihad might have faded away but for the continuous presence of these troops' (Sageman 2004: 40). After 11 September 2001, the war in Afghanistan pushed Salafi jihadists to look for protection in other countries such as Pakistan and Iran, disseminating military skills and ideological motivations (Hafez 2007: 166ff.). Similarly, resistance to the US invasion of Iraq involved a heterogeneous coalition, made up of Salafi jihadists and members of Hussein's socialist Ba'ath Party, again with an important role for former soldiers and secret service officers (Hafez 2007: 37). After the withdrawal of Soviet troops in 1989 and the appearance of internal divisions in the resistance, many fighters 'largely returned to domestic economies with limited opportunities and to highly charged political environments where the "Afghans", as they were called, were immediately deemed politically suspect and suspicious, due to their travel' (Singerman 2004: 158). Some of those who had fought in Afghanistan then moved to Bosnia, where, in 1992, Bosnian Muslims had rebelled against a self-proclaimed independent state for fear of Serbian 
violence. The Arab Afghanis arrived, expelled from Afghanistan as displaced men who:

faced a serious problem, because return to their countries of origin meant certain arrest, torture, and likely death. At the time, a Saudi spokesman for the Arab-Afghans in Jeddah explained in the media, 'the Algerians cannot go to Algeria, the Syrians cannot go to Syria, or the Iraqis to Iraq. Some will opt to go to Bosnia, the others will have to go into Afghanistan permanently.' (Kohlmann 2004: 16)

So, 'hundreds of Arab mujahideen veterans caught in the civil turmoil in Afghanistan and with nowhere to go found asylum in Bosnia' (Kohlmann 2004: 11). There, they met European Muslims; one of the effects of this encounter was that Arabic books were translated into European languages and the activists began to use computers. Of about 700 foreign fighters in Bosnia, many came from Egypt, with experiences in the student movement and/or in the Islamic Group (al-Gama'a); others came from Saudi Arabia; still others came from Europe, where they or their families had migrated and they had sometimes been active in Muslim charities. For many of them, the war in Bosnia was to be read not as one of Serbians against Muslims, but as one of Christianity against Islam (Kohlmann 2004: 25).

Opportunities are observed to be diminishing in both older and more recent cases of radicalization, but this is not always the case. In Spain, radicalization occurred during transition, in part as a reaction to its inconsistencies, in part as a way to put pressure on the changing institutions. Ambivalence has also been noted in the Spanish case. If, after the death of Franco, Prime Minister Suarez's politics were oriented towards compromise, they remained particularly ambivalent towards Basque nationalism. Weak support for the legalization of Basque symbols (such as the ikurrina flag) and the exclusion of ETA prisoners from pardons in 1975 and 1976 in turn reduced support in the Basque Country for the constitution. More generally, for many years the policing of protest often remained tough. The Public Order Law was not amended until 1991, and 'the antiriot units continued to respond to breach of the public order in almost the same way as before: between 1975 and 1979, the police caused the deaths of thirty-six people in street confrontations. Not even the approval of the new democratic Constitution in 1978 proved a definite turning point' (Jaime-Jiménez and Reinares 1998: 170).

Brutal and indiscriminate repression is not always directly the basis for political violence. In some cases, inconsistent repression 
comes to the fore instead. The Italian extreme right committed its most brutal massacres when it was supported by part of the state; this protection led neo-fascists not only to expect impunity but also gave them the potential to achieve their aims of establishing an authoritarian state. This was also in part true for the anti-ETA vigilantes in Spain, who committed their crimes while enjoying the tacit indifference or even active help of some Spanish institutional apparatuses. Even in the authoritarian regimes in the Middle East, inconsistency has characterized state attitudes towards Islamist movements, which have been tolerated or even supported - as allies against the Left and/or nationalist movements - in some periods, repressed in others.

\section{Emotional Mechanisms}

Emotional mechanisms developed during interactions in the street, as emotionally charged events favoured radicalization, through processes of identification. Both negative and positive emotions played a role in motivating radical action. In several cases, tough policing was a vivid memory. Italian left-wing activists recalled fights with the police: 'I still have a rain coat, I've always kept it, with a hole made by a tear gas bullet' (Life history no. 21: 310), 'furious clashes until 2 p.m., from 5 a.m. to 2 p.m.' (Life history no. 5: 86); 'a policeman who aimed his gun at my belly' (Life history no. 21: 31); 'my burnt hand, when I tried to throw back a squat candle' (Life history no. 3: 19).

These encounters aroused intense emotions, such as excitement, and strengthened commitment to radical politics. Thus, a future member of a clandestine left-wing organization described his first demonstration, in Milan in the late 1960s:

We were looking for other classmates, quietly walking in the street, when pandemonium broke out: tear gas, cries, blows, people running everywhere. In the beginning, we did not realize what was happening. We had our share of tear gas and we tried to run away ... We wandered around in the city center, looking for the march, following the smoke and the cries. We saw a squad of policemen in combat gear. It was all very spectacular: tricolour bands, the trumpets to start the charges. I saw Milan in a way I would never have imagined, with the smoke of the tear gas, and a really ghostly scene: torn placards, broken road-signs, and people wounded in the street . . . I arrived home very late. My eyes were red from the smoke of the tear gas, my clothes were torn. But I was so happy and excited, because something very important had happened, and I had been there. (Life history no. 12: 10-11) 
Events such as the massacre in Piazza Fontana in Milan in 1969 had a high emotional impact. As a militant recalls,

Of course, interest rose after the fascist massacre of Piazza Fontana, on December 12, 1969. For the first time, there was a strike. We did not go to classes, but went to the funeral in Piazza Duomo. There was a huge public march and the Mass. I remember that, with a lot of effort because it was packed with people, I entered the Duomo. There were all these biers. (Life history no. 12: 10)

The mobilization after the massacre and the death of an anarchist, Pinelli, while being interrogated by police during the investigation represented very intense experiences for many activists.

In death, comrades became heroes. Extreme emotions were aroused by the memory of the 'April days' of 1975, 'Three days of fighting . . . following the assassination of the young Varalli by a group of neo-Fascists, and of Zibecchi, crushed by a police car in front of the MSI [Italian Social Movement - Movimento Sociale Italiano - a neo-Fascist party] headquarters' (cited in Novelli and Tranfaglia 1988: 163). These 'were the moments when rage and the desire to rebel came to possess us all ... Those deaths gave us a strange feeling, almost as if it were not possible to go back any more' (cited in Novelli and Tranfaglia 1988: 206). In the second half of the 1970s, the list of left-wing activists killed by police during protests or after arrests grew, and with it the highly emotional moments of the victims.

Similarly, on the right, memories of friends who died at the hands of the police or political adversaries are common. Often remembered were the January 1978 Acca Larentia attacks in Rome, when three right-wing militants lost their lives in an attack by radical leftists of the Armed Group for Territorial Counterpower (Nuclei Armati per il Contropotere Territoriale) against the Italian Social Movement headquarters in via Acca Larentia. Two of the activists were killed by political adversaries, one by police who had intervened to quell the fights. As Armed Revolutionary Group activist Francesca Mambro recalled, 'At Acca Larentia ... for the first time, and for three days, the fascists fired at the police. And this was obviously a point of no return' (Ferraresi 1995: 293). Also in this period, a young Italian Social Movement activist, Alberto Giaquinto, was killed by police officers during an attack on a Christian Democrat party section.

In the Basque Country older militants also recalled the rage that followed their direct experiences with violent repression during 
Franco's regime and immediately after his death. As one of them recalled: 'I was arrested . . . I went with a girl to dance, in a dancing place, where they played songs in euskera [the Basque language]. ... Suddenly, the guardia civil entered and charged. They charged although there was no demonstration of any type. And they entered the sala de fiesta with ten jeeps' (Reinares 2001: 133). Particularly intense are the memories of torture once in the hands of the police: 'I remember . . . it was 1976 and the day of euskera [the Basque language]. I have it written in my memory. Our group of people, we did not sleep. They did not let us sleep. We stayed for six days without sleeping. And there were constant threats. The pistol at your head ...' (Reinares 2001: 139). Another recalled, 'I was in prison for ten days. They hit me. We just wanted to be independent' (Reinares 2001: 154).

While the memory of past repression remained alive, the opening up of political opportunities during the transition did not moderate political violence; instead it increased because, as mentioned, the process of de-escalation was slow and at times inconsistent. The struggle against repression then became emotionally charged. Among the events that triggered their politicization, the Basque militants remembered, as well as with the Burgos trials with the last death penalties before Franco's death, the March for Freedom organized in July 1977 to ask for amnesty and self-government. An activist thus recalled the climate during the protest for amnesty during the democratic transition:

I was very, very marked by the March for Freedom. I was fifteen. The March for Freedom was a march that went through all Euskadi with four columns that converged in Iruna. And, in fact, you went in the march when it went through your village. And you shared your food, and they slept in peoples' places . . . And so I started to know people who were not of my village, who were from Guiputzca, had a brother or a friend in prison, people who had another brother or friend in exile. And for me it was very strong, because I lived it with much intensity. (Reinares 2001: 78)

Tensions remained high after the transition to democracy, as 'the elites of the Franco regime continued to play an important role in the political decision making of the state' (Reinares 2001: 173). In the Basque Country, the 'pacted transition' was therefore not sufficient to legitimize a Spanish state accused of following the Fascist tradition, established during the long-standing Francoist regime, of resorting to torture against Basque patriots. Franco's 
death produced many expectations that were ultimately frustrated, at least in the short term. In the words of an activist, 'we all thought that, when Franco died, we were going to have a reunified Euskadi, euskaldun [Basque-speaking], independent, socialist' (Reinares 2001: 102). After the death of Franco and during the democratic transition, the absence of purges was considered a sign of continuity with the former regime; as an activist recalled, 'Franco died and everything went on' (Reinares 2001: 123).

During transition and consolidation, the continuation of repression and military presence in the Basque Country was felt as to be an attack on the community. ${ }^{2}$ As an ETA militant recalled,

Well, at the level of the environment, in the streets, you could not go quietly with your friends. Because a jeep arrived or two guardia civil, and they asked for your documents with bad manners, throwing you against the wall. It was an environment of absolute repression. Everything was repression ... I remembered that three or four buses of the guardia civil arrived and at least 40 jeeps. They came here and took the village. They took it militarily. They entered in the houses. (Reinares 2001: 134)

Feelings of injustice increased the identification with a repressed community. Another Basque activist remembered, 'I saw a guardia civil hitting a pregnant woman because she spoke euskera . . . the guardia civil asked the pregnant woman why she was speaking euskera. He told her, it was the language of the terrorists, and that she had to speak Spanish as we were in Spain' (Reinares 2001: 130).

Strong emotions developed at the funerals of patriots killed by violent anti-ETA groups. An ETA member remembered, "with this friend, we went to the funeral of someone who had been killed by the GAL [Anti-terrorist Liberation Group - Grupo Antiterroristas de Liberación]. I was sixteen . . . it was a very small village. All the people went to the funeral. There was then a demonstration. And we saw the guardia civil on the mountains. On all the mountains' (Reinares 2001: 79). The imprisonment of ETA supporters (and suspected supporters) also continued to provide motives for frequent and emotionally intense mobilizations. All these memories of interactions between state and activists created mistrust and hampered the potential for the de-escalation of violence. A Basque militant recalls, 'Well, those who entered ETA, more than for an ideology, it was because their heart told them to' (Reinares 2001: 158).

In the case of Islamic fundamentalism, the repression by authoritarian regimes in countries such as Egypt and Saudi Arabia, 
as well as participation in civil wars (especially in Afghanistan and then in Bosnia), represented a particularly intense emotional experience for those who participated directly, and also for those who learned about them and identified with those fighting. In the early 1990s, in addition to the imposition of curfews and police occupations of entire villages (such as Imbaba, Dairut or Mallawi), repression hit family members of suspected Islamists and, especially after violent confrontations, men wearing beards. During curfews, 'Hundreds of residents were arrested, houses of alleged members of al-Jamaa were destroyed, and their families were taken into custody. With electricity cut off, markets dissolved, and sugar cane fields were eradicated because militants used them to hide during ambushes. Economic activities in the villages were almost brought to a standstill' (Malthaner 2010: 240).

Repression in the form of collective punishment produced waves of solidarity with those who were perceived as defending the community. As in the Basque Country, the state responded to disturbances by militarizing the territory of the suspected community. In Malthaner's reconstruction,

the Egyptian security forces' repressive and violent reaction severely affected living conditions and put towns and village communities under enormous pressure. From the early 1990s on, Egyptian police deployed a large number of forces in Upper Egypt and carried out brutal and arbitrary arrest operations against alleged strongholds in a manner which resembled, as one observer remarked, punitive expeditions in the tradition of Cairo's semicolonial rule over its southern provinces. Suspects could be held without trial under emergency law, and in the mid-1990s human rights organizations put the number of political prisoners in Egypt at an estimated 20,000 to 30,000 , most of them alleged Islamist activists. Military courts handed out a large number of death sentences (more than 80) and several hundred alleged al-Jamaa members were killed during arrest operations by the police. (Malthaner 2010: 167-8)

During the resistance to the Soviet occupation, thousands of Arab Afghans - many from upper- and middle-class families of the Arab Gulf region - joined the various groups of mujahideen with headquarters in Peshawar, Pakistan. This helped develop the notion of universal Muslim brotherhood. Notwithstanding some tensions with the Afghans, participation on the battlefield fostered feelings of solidarity. One declared: 'For me, this battle was really a big boost that motivated me to carry on. It gave us the assurance that no one is hit except if that was destined for him by Allah' (Kohlmann 2004: 13). 
Another indicated: 'The Jihad in Afghanistan was a great experience. Whoever was involved in this experience had the great desire that Allah would keep them engaged in the Jihad' (Kohlmann 2004: 17). Osama bin Laden himself stated, 'What I lived in two years there, I could have not lived in a hundred years elsewhere' (cited in Esposito 2002: 9).

The war in Afghanistan was an intense emotional moment for several of those who later joined al-Qaeda. For many of them, Bosnia was another step in the global jihad. In Bosnia, militants recalled their direct experiences with the atrocities of the war. One of them remembered, 'I saw people who died', 'I saw a ten year old child who burned alive in Bosnia. It was a genocide' (Kohlmann 2004: 115) and 'I had a Kalashnikov in my hands. I was blessed twice. I saw corpses' (Kohlmann 2004: 119).

\section{Cognitive Mechanisms}

Escalating policing produced cognitive effects, as the everyday experiences of fights with police supported the construction of an image of the state as unfair. In all of our cases, direct experiences of state repression produced radicalization. Beyond the immediate experience of fighting, the construction of the repression was also important. The state that is 'firing at me', or at my community, was perceived as an unjust state. As Hafez (2004: 53) noted, anti-system radical frameworks 'gained empirical credibility in the context of state repression and provided a rationale for the expansion of violence that included anyone supporting the regime and its legitimacy'.

In our cases, repression increased the perception that there was no other way out; it was read as proof of the need to take up arms to resist an authoritarian state. In fact, the more exclusionary a regime, the more it tends to incubate violent action, as 'those who specialize in it tend to prosper, because they come to be viewed by many people as more realistic and potentially effective than political moderates, who themselves come to be viewed as hopelessly ineffective' (Goodwin 1997: 18).

State repression - as 'suffered violence' - justified radical responses. As an Italian left-wing activist explained:

It is first of all a problem of suffered violence. The first images are linked to the police charges. The first, strong signs of an unsustainable situation, a situation which really had to be changed, come in those years from Avola 
and Battipaglia. They came from those demonstrations, by the way not student ones, that were hit and repressed, with the death of people who had demonstrated ... the first demonstrations in which there were clashes . . I did not remember them as having been planned. (Life history no. 9: 243)

At the same time, the perception of the involvement of state institutions in massacres and coups increased mistrust in the democratic quality of the existing system. At critical junctures, the exceptional moment is seen as requiring exceptional commitment. Again, in the words of an Italian left-wing militant,

This is the period just after the military coup in Chile. We started to feel the need to defend ourselves. This argument was for me absolutely convincing. I was certain that any mass struggle that was to approach power could never reach it without a very violent fight. The massacre of Piazza Fontana testified to it. While Vietnam was for me very far away, I had felt the experience of the Popular Front in Chile as very near to the Italian one. Consider, too, that there was very widespread paranoia about an imminent fascist coup. (Life history no. 12: 17)

Left-wing activists also remembered feeling as if they were living in a historic moment, remembering 'periods when I had my backpack already prepared under my bed' (cited in Novelli and Tranfaglia 1988: 122) and 'How many people - I do not refer only to the comrades of the extra-parliamentary left - did not sleep at home; how many eyes were focused on the barracks' (cited in Novelli and Tranfaglia 1988: 204). The 'paranoia of a coup d'état' brought about 'a conspiratorial identity' (Life history no. 18: 47); 'What to do when there is a coup d'état was the classic book that all the comrades had hidden on their bookshelves', added another (Life history no. 6: 19). If no other way out was perceived as available, however, activists also remembered having high expectations that change would happen. Several Italian left-wing activists mentioned the impression that they were experiencing a historic time. A Neapolitan activist recalled that, in talking about a revolution, "we asked ourselves . . " "how many years would be necessary?", “oh, I think only a few. Probably ten'” (Life history no. 2: 388).

For Italian radical right-wingers as well, these years were certainly seen as intense in terms of expected changes, as hidden support by the secret services raised suspicions of a possible turn towards an authoritarian regime. Contacts with the secret services were in fact admitted to from inside the radical right. In an interview, Pino Rauti 
assigned the responsibility of the Piazza Fontana massacre to the secret service and the strategy of tension, admitting that his organization, New Order (Ordine Nuovo, ON), 'had collaborated with the state in the name of a common enemy' (Cento Bull 2007: 115). In a climate of fear and witch-hunting, according to yet another right-winger,

The preferred scheme was that after the Second World War, in order to face the communist danger, Italian sectors within the armed forces and among the industrialists, which in turn were controlled by the CIA, recruited some veterans of the Social Republic, who were viscerally anti-communist and trained them as sappers and guerrillas ... Obviously for the people who came from the experience of the Social Republic the memory of the purges and systematic executions was still alive and vivid, with the foibe in the region Venezia-Giulia and the massacres, the mass killing in the Emilia triangle. (Cento Bull 2007: 117)

Likewise, in the Basque case, the brutal repression of Franco's dictatorship strongly legitimized a violence that was considered necessary in the face of an authoritarian regime. First, the brutality of the regime was seen as justifying self-defensive violence, as, in the words of a Basque activist, 'It was them who used violence. It is in a situation of dictatorship, like Francoism. Its form of relations with us was violence' (Reinares 2001: 89). Revenge became legitimized as a normal reaction to the violence of the other: 'When I'm tired of getting them, I have to give the same back to them, no?' (Reinares 2001: 137). A widespread perception was that 'Of course you had to resort to violence. Given that the regime, which is repressing you, is a violent regime. Of course, they are resorting to violence continuously; clearly, they put you in prison, they torture you' (Reinares 2001: 87). At the same time, repression by the centre reduced the legitimacy of Spain as a nation: for the Basque militants, in the words of one of them, 'Franco represented Spain' (Reinares 2001: 163), and 'Spain? Repression. Spain was the police' (Reinares 2001: 166). Consequently, ETA gained credibility as the most effective group under highly repressive circumstances. The choice of a clandestine and violent organization thus started to appear quite normal; as an activist remembered, 'To enter in ETA? No, in some way, I did not ask myself. That is, my problem is that it was the only way of doing politics, to attack a regime violently, because there was no other way of doing politics' (Reinares 2001: 87). 
Direct and indirect memories of repression are often cited as forging a discourse that motivates people to rebel. Violence becomes justified as the self-defence of a community:

much more than the social and nationalist aspects, it was the intensity with which I lived the repression of our country ... It was not that I was especially mistreated ... It was that they killed us, fired at us, or at the very least they did not allow us to be minimally free, right? At least, I felt it this way. I thought it was an expression of rage, of response to repression, but more as self defence. (Reinares 2001: 129)

Similarly, the heavy repression of Islamist (and other) protests by authoritarian regimes in the Middle East played an important and dramatic role in the radicalization of Islamic movements. As Hafez (2004: 40) observed, repression was particularly relevant here, as 'movements under a repressive environment accumulate material and organizational resources slowly and must be careful not to lose them to state repression. To overcome this problem, movement organizations must find ways to absorb the inevitable blows of state repression without suffering disintegration.' In Saudi Arabia as well, arrests and mistreatments had powerful effects in terms of producing mistrust towards state authorities, which were perceived as betraying their own commitments. As a militant explained,

we went out to Bosnia to defend our brothers with the encouragement of the [Saudi] television and its ulama. So we went there and came back, only to find prison and torture. I personally stayed in a cell for a year and three months for no reason whatsoever, except that I had gone to Bosnia. Many of the brothers were imprisoned ... and they were tortured systematically. (Hegghammer 2010: 75)

In fact, 'the shock of the maltreatment was amplified by the fact that the detainees had perceived their activities abroad as entirely legitimate and even encouraged by the state. A common theme in the Saudi jihadist literature is the profound bitterness about the state ingratitude towards the sacrifice of the jihadists' (Hegghammer 2010: 75).

More generally, the perceived sense of injustice among those who had fought in Afghanistan enhanced their solidarity. 'The "criminalization of politics" produced activists and sympathizers who create their own political world, with different rules and norms, where the transcendental ends justifies the means' (Hegghammer 2010: 164). In an international environment, claims quickly become 
global: 'It is the global situation that pushed me towards theology' (Hegghammer 2010: 101). Violence was perceived as the only way to achieve independence: 'Writing, demonstrating, it is useless. It is demagogic. It is like doing nothing' (Hegghammer 2010: 104). In the words of another fighter, 'Afghanistan was our school . . . instead of fighting the Communist Russians outside Kabul, we are now fighting the Communist Chetniks (Serbs) outside Travnik. Even their tanks are the same. In Afghanistan, we hit the T-55s in the mountains. Here, we hit T-55s in the mountains' (Hegghammer 2010: 92). The armed diaspora continued after the Dayton Agreements, which imposed the expulsion of foreign fighters: 'We the Arab felt that our staying in Bosnia was not desirable anymore . . . we were compelled to flee to Kosovo' (Hegghammer 2010: 200).

Finally, in the West, the 'war on terrorism', read as war on Islam, contributed to the spread of injustice and the politicization of religious identities. In both situations, repression tended to be perceived as aggression towards pious religious communities, politicizing and radicalizing religious identities.

\section{CONCLUSION}

In considering clandestine political violence as extreme violence perpetrated by political groups active in the underground, I have looked at the field of social movements for inspiration. Following that literature, I have considered the evolution of violence as embedded in social and political conflicts, influenced by the political opportunities available to elites and challengers as well as the material and cognitive resources available to contenders. Building on some important innovations in the area, I suggest that violence could not be satisfactorily explained by looking exclusively at structural conditions. Clandestine forms of violence, in particular, are in fact embraced by tiny minorities that react with radicalization to conditions that lead others towards moderation.

Rather than emphasizing teleological or behavioural explanations, I have built on what Charles Tilly (2004) called a relational perspective. In all my cases, processes of radicalization took place during the interactions between various collective actors, including social movement organizations and state institutions. The relationships between these actors change both in cooperation and in competition. 
I have also emphasized the constructed nature of the process: that is, we must consider not contextual conditions but rather the perceptions of those conditions - the 'attribution of opportunities' in McAdam et al.'s (2001) language. Commonly noted was the perception that opportunities for peaceful protest were narrowing but also that conditions conducive to violent action were opening up.

Furthermore, I have stressed that violence developed over long periods: conditions were not only pre-existing, but also formed in action. In this sense, violence is an emergent phenomenon, reproducing in action the conditions for its very development. As Beissinger (2002) observed, events are constitutive of identity; moreover, they force actors to take positions (Sewell 1996).

My attempt at global comparisons - which I defined as based on a small-N comparison of critical cases, chosen using a most-different research design - brought me to the search not for root causes but for causal mechanisms as categories of action filtering structural conditions and producing effects. No doubt, the degree of economic development, democratic qualities and national cultures vary broadly among the historical cases I have analysed as illustrations of left-wing, right-wing, ethno-nationalist and religious types of clandestine political violence. However, my analysis has also shown some similarities in the mechanisms that underlie the radicalization of political conflicts and sustain clandestine political violence.

Escalating policing emerged as a common mechanism at the onset of clandestine political violence. Protest, as a challenge to public order, normally brings about interactions of protestors with police, who have to defend the status quo. Strategies of protest policing, however, vary broadly. The police can privilege the right to demonstrate over the disturbances to public order and can tolerate minor violations. They can rely on softer or harder tactics when they intervene, using persuasion or force. Their intervention can be not only more or less brutal, but also more or less focused on 'troublemakers'. As Tilly (1978) suggested, what distinguishes regimes is a variable mix of facilitation of some groups and forms of participation, and repression of others.

In all our cases, in a process of double diffusion (della Porta and Tarrow 2012), the radicalization of the forms of protest interacted with repressive styles that were brutal and often diffuse, hitting not only violent militants but also non-violent ones. Tactical interactions 
developed through reciprocal adaptation to innovative turns, so that each side's choices were influenced by those of the adversary (McAdam 1983). Violence spread as the state was perceived as overreacting to the emergence of protest. This was the case in Italy, when the student movement and then the labour movement protest signalled a growing conflict, even more in Franco's Spain, when labour protest met ethnic revival, and in the authoritarian regimes in the Middle East which reacted strongly to the so-called religious awakening.

In fact, repeated experiences of physical confrontation with police created an image of an unfair state ready to use brutal force against its citizens. The more the repression was perceived as indiscriminate, the more solidarity with the militant groups increased; this was particularly the case in Franco's Spain and under the authoritarian regime of Mubarak in Egypt or the Israeli occupation in Palestine. These types of police actions delegitimized not only the police, but also the state that the police claimed to serve. Moreover, perceptions of injustice increased when the state was seen as taking sides, repressing some groups' violent behaviours but tolerating the violence of others - as was the case with the radical right in Italy. Repression created subcultures sympathetic to violence, often resuscitating old myths, and so violence itself started to be perceived as a resource in the internal competition within the social movement family. Escalation was facilitated not only by indiscriminate repression, but also by inconsistent repression. For the Italian right-wingers as well as for the Islamists in Saudi Arabia, feelings of disunity were created by what the groups saw as a betrayal by a state that had been somewhat supportive of their cause. So, repression was perceived as unjust (Gamson et al. 1982).

Repression, in fact, produced transformative events (Beissinger 2002; della Porta 2008b, 2014; Sewell 1996). Brutal treatment of demonstrators or the killing of comrades are recalled by left-wing, right-wing, ethno-nationalist and religious militants alike as fuelling intense emotions of solidarity with a community of fighters and the designation of the state as an enemy. It created martyrs and recreated myths. Read within a broader narrative of oppression and resistance, heavy repression was framed as an indication that there is no other way out. This means mistrust in peaceful means of protest and, at the same time, confidence in the effectiveness of violence. 
Without satisfying a taste for general theories, I hope, however, that the discovering of these similar mechanisms can take us forward in the understanding of clandestine political violence. In particular, in times in which every new wave of clandestine political violence is presented as peculiarly evil and irrational, I hope that this article has provided enough evidence on the existence of similar mechanisms to stimulate further comparative analysis of different types of violence.

\section{ACKNOWLEDGEMENTS}

This article develops on my Government and Opposition/Leonard Schapiro Memorial Lecture given at the Political Science Association General Conference in Cardiff in March 2013, as well as the first chapter of my Clandestine Political Violence (2013). I am grateful to Cambridge University Press for the permission to use some material from the book. I worked on the text while being Advanced Grantee of the European Research Centre. I am grateful to the ERC for their support, while the responsibility for what I have written remains, of course, mine.

\section{NOTES}

1 The Life Histories referred to in this article are biographies of activists of underground organizations that I have collected through in-depth interviews. For more details, see della Porta (2013: ch. 1).

${ }^{2}$ In this period, the Basque Country remained the most militarized in Spain. In the 1980s, as many as 17 per cent of the Spanish troops were deployed in an area that covered only 3.5 per cent of Spanish territory. Repression was perceived as permeating everyday life.

\section{REFERENCES}

Aminzade, R. and McAdam, D. (2001), 'Emotions and Contentious Politics', in R. Aminzade, J. Goldstone, D. McAdam, E. Perry, W.H. Sewell Jr, S. Tarrow and C. Tilly (eds), Silence and Voice in the Study of Contentious Politics (Cambridge: Cambridge University Press): 51-88.

Beissinger, M.R. (2002), Nationalist Mobilization and the Collapse of the Soviet State (Cambridge: Cambridge University Press).

Berntzen, A.L.E. and Sandberg, S. (forthcoming), 'The Collective Nature of Lone Wolf Terrorism: Anders Behring Breivik and the Anti-Islamic Social Movement', Terrorism and Political Violence.

Burawoy, M. (2005), 'Provincializing the Social Sciences', in G. Steinmetz (ed.), The Politics of Methods in the Social Sciences (Durham, NC: Duke University Press): 508-25.

(C) The Author 2014. Published by Government and Opposition Limited and Cambridge University Press 
Cento Bull, A. (2007), Italian Neofascism. The Strategy of Tension and the Politics of NonReconciliation (Oxford: Berghahn Books).

Crenshaw, M. (2011), Explaining Terrorism: Causes, Processes and Consequences (London: Routledge).

Della Porta, D. (1995), Social Movements, Political Violence and the State (Cambridge: Cambridge University Press).

(2008a), 'Comparative Analysis: Case-oriented versus Variable-oriented Research', in

D. della Porta and M. Keating (eds), Approaches and Methodologies in the Social Sciences:

A Pluralist Perspective (Cambridge: Cambridge University Press): 198-222.

— (2008b), 'Eventful Protests, Global Conflicts', Distinktion, Scandinavian Journal of Social Theory, 17: 27-56.

(2013), Clandestine Political Violence (Cambridge: Cambridge University Press).

- (2014), Mobilizing for Democracy (Oxford: Oxford University Press).

— and Reiter, H. (1998), Policing Protest: The Control of Mass Demonstrations in Western

Democracies (Minneapolis: University of Minnesota Press). (2004), Polizia e Protesta (Bologna: Il Mulino).

and Tarrow, S. (2012), 'Double Diffusion: Police and Protestors in Transnational

Contention', Comparative Political Studies, 20: 1-34.

Dutton, M. (2005), 'The Trick of Words: Asian Studies, Translation, and the Problem of Knowledge', in G. Steinmetz (ed.), The Politics of Methods in the Social Sciences (Durham, NC: Duke University Press): 89-125.

Engene, J.O. (2004), Terrorism in Western Europe (Cheltenham: Edward Elgar).

Esposito, J.L. (2002), Unholy War: Terror in the Name of Islam (New York: Oxford University Press).

Eyerman, R. (2005), 'How Social Movements Move: Emotions and Social Movements', in H. Flam and D. King (eds), Emotions and Social Movements (London: Routledge): $41-57$.

Fernandez, L.A. (2008), Policing Dissent: Social Control and the Anti-Globalization Movement (London: Rutgers University Press).

Ferraresi, F. (1995), Minacce alla democrazia. La Destra radicale e la strategia della tensione nell'talia nel dopoguerra (Milan: Feltrinelli).

Flam, H. (2005), 'Emotions' Map: A Research Agenda', in H. Flam and D. King (eds), Emotions and Social Movements (London: Routledge): 19-41.

Gamson, W.A., Fireman, B. and Rytina, S. (1982), Encounters with Unjust Authorities (Homewood, IL: Dorsey Press).

Goodwin, J. (1997), No Other Way Out (Cambridge: Cambridge University Press).

- (2004), 'Review Essay: What Must we Explain to Explain Terrorism?', Social Movement Studies, 3: 259-65.

— Jasper, J. and Polletta, F. (2001), Passionate Politics: Emotions and Social Movements (Chicago: University of Chicago Press).

Hafez, M.M. (2004), 'From Marginalization to Massacres: A Political Process Explanation', in Q. Wiktorowicz (ed.), Islamic Activism: A Social Movement Theory Approach (Bloomington: Indiana University Press): 37-60.

- (2007), Suicide Bombers in Iraq: The Strategy and Ideology of Martyrdom (Washington, DC: USIP Press). 
and Wiktorowicz, Q. (2004), 'Violence as Contention in the Egyptian Islamic Movement', in Q. Wiktorowicz (ed.), Islamic Activism: A Social Movement Theory Approach (Bloomington: Indiana University Press): 61-88.

Hall, P.A. (2003), 'Aligning Ontology and Methodology in Comparative Research', in J. Mahoney and D. Rueschemeyer (eds), Comparative Historical Research (Cambridge: Cambridge University Press): 373-404.

Hedstrom, P. and Bearman, P. (2009), 'What is Analytic Sociology all About? An Introductory Essay', in P. Hedstrom and P. Bearman, The Oxford Handbook of Analytic Sociology (Oxford: Oxford University Press): 3-15.

Hegghammer, T. (2010), Jihad in Saudi Arabia: Violence and Pan-Islamism since 1979 (Cambridge: Cambridge University Press).

Jaime-Jiménez, O. and Reinares, F. (1998), 'The Policing of Mass Demonstrations in Spain', in D. della Porta and H. Reiter (eds), The Policing of Mass Demonstrations in Contemporary Democracies (Minneapolis: University of Minnesota Press): 166-87.

Kalyvas, S. (2006), The Logic of Violence in Civil Wars (Cambridge: Cambridge University Press).

Kohlmann, E. (2004), Al Qaida's Jihad in Europe: The Afghan-Bosnian Network (Oxford: Berg).

Laqueur, W. (2003), No End to War: Terrorism in the Twenty-First Century (New York: Continuum).

McAdam, D. (1983), 'Tactical Innovation and the Pace of Insurgency', American Sociological Review, 48: 735-54.

— Tarrow, S. and Tilly, C. (2001), Dynamics of Contention (Cambridge: Cambridge University Press).

Mahoney, J. (2003). 'Tentative Answers to Questions about Causal Mechanisms', paper presented at the meeting of the American Political Science Association, Philadelphia, 27 August.

- and Goertz, G. (2006), 'A Tale of Two Cultures: Contrasting Quantitative and Qualitative Research', Political Analysis, 14(3): 227-49.

Malthaner, S. (2010), Mobilizing the Faithful (Frankfurt am Main: Campus Verlag).

Mayntz, R. (2003). Mechanisms in the Analysis of Macro-Social Phenomena, MPIfG Discussion Paper 03/3 (Cologne: Max Planck Institute for the Study of Societies).

Novelli, D. and Tranfaglia, N. (1988), Vite sospese: Le generazioni del terrorismo (Milan: Garzanti).

Reinares, F. (2001), Patriotas de la muerte: Quiénes han militado en ETA y por que? (Madrid: Taurus).

Sageman, M. (2004), Understanding Terror Networks (Philadelphia: University of Pennsylvania Press).

Sewell, W.H. (1996), 'Three Temporalities: Toward an Eventful Sociology', in T.J. McDonald (ed.), The Historic Turn in the Human Sciences (Ann Arbor: University of Michigan Press): 245-80.

Singerman, D. (2004), 'The Networked World of Islamist Social Movements', in Q. Wiktorowicz (ed.), Islamic Activism: A Social Movement Theory Approach (Bloomington: Indiana University Press): 143-63. 
Tarrow, S. (1989), Democracy and Disorder: Protest and Politics in Italy, 1965-1975 (Oxford: Oxford University Press).

Taylor, M. and Horgan, J. (2012), 'A Conceptual Framework for Addressing Psychological Process in the Development of the Terrorists', in J. Horgan and

K. Braddock (eds), Terrorism Studies: A Reader (London: Routledge): 130-44.

Tilly, C. (1978), From Mobilization to Revolution (Reading, MA: Addison Wesley).

- (2001), 'Mechanisms in Political Science', Annual Review of Political Science, 4: 21-41.

(2003), The Politics of Collective Violence (Cambridge: Cambridge University Press). (2004), 'Terror, Terrorism, Terrorists', Sociological Theory, 22: 5-13.

Wood, E.J. (2003), Insurgent Collective Action and Civil War in El Salvador (Cambridge: Cambridge University Press). 